\title{
Biofloc based nutrient dense culture system for nursery and grow-out farming of Pacific white shrimp Penaeus vannamei Boone, 1931
}

\author{
A. PANIGRAHI, M. SUNDARAM, J. JEBHA, J. SYAMADAYAL, S. K. OTTA, \\ T. BHUVANESWARI, R. SARASWATHY, P. S. SHYNE ANAND, D. RAJABABU, \\ C. SARANYA, C. GOPAL AND P. RAVICHANDRAN \\ ICAR-Central Institute of Brackishwater Aquaculture, 75 Santhome High Road, R. A. Puram, Chennai - 600028 \\ Tamil Nadu, India \\ e-mail:panigrahi@ciba.res.in,apanigrahi2k@gmail.com
}

\begin{abstract}
The concept of "biofloc technology" is changing the facet of intensive aquaculture with scope to attain high productivity in a sustainable manner. In biofloc, dense heterotrophic bacterial community is developed through $\mathrm{C}: \mathrm{N}$ ratio manipulation, where the system becomes bacterial dominated rather than algae dominated and takes care of the wastes generated through in situ bioremediation. Protein is utilised in two ways; as feed for the shrimp and as microbial floc when the heterotrophic microbes convert the nitrogenous wastes into protein. It also promises a healthy rearing system, which is increasingly identified as one possible solution for disease problems especially those striking at early stages. The purpose of this study was to evaluate the effect of biofloc and periphyton technology (BPT) on the growth and immunomodulatory performance of Pacific white shrimp Penaeus vannamei during nursery and grow-out culture. The experimental BPT treatments with three tier substrate system with molasses as carbohydrate $(\mathrm{CHO})$ source were compared with the conventional autotrophic system. The immunomodulation and cumulative percentage mortality upon challenge with pathogenic strain of Vibrio parahaemolyticus were assessed in the reared animals. We have successfully demonstrated the BPT based nursery and growout systems for $P$. vannamei with the advantage of providing significantly $(\mathrm{p}<0.05)$ better growth $(27.6 \%$ improvement in average body weight, $\mathrm{ABW}$ ) and feed utilisation (31\% improvement in feed conversion ratio, FCR). A production level of $4-4.5 \mathrm{~kg} \mathrm{~m}^{-3}$ of water was achieved through this BPT system registering a significant improvement over the conventional system $(p<0.05)$. The cumulative percentage mortality following pathogen challenge was significantly lower $(p<0.05)$ in the biofloc grown shrimps compared to that of the control group, thus showing better resistance to pathogenic challenge. Furthermore, the biofloc reared shrimp did exhibit significant improvement in non-specific immune response in terms of serum phenoloxidase activity and total haemocyte counts possibly suggesting potential immunostimulatory role of the biofloc associated heterotrophic bacteria. This eco-based technology as revealed through our studies brings substantial improvement in productivity, minimising water requirement, recycling in situ nutrients and organic matter in turn improving farm biosecurity, augmentation of natural food, improvement of FCR and better health of the cultured shrimp.
\end{abstract}

Keywords: Biofloc and periphyton technology, BPT, Heterotrophs, Immunomodulation, Microbial floc, Penaeus vannamei

\section{Introduction}

Biofloc and periphyton technology (BPT) is a relatively new biotechnological means to support high density culture, maintain water quality, biosecurity, reduce the need for water exchange, reutilise the feed and reduce the production cost. The flocculated microorganisms produced through this process are denser and tend to settle down at the bottom. By developing dense heterotrophic bacterial community, the system becomes bacteria-dominated rather than algae and takes care of the waste generated in the system through in situ bioremediation. Disease outbreaks and their impact on commercial shrimp farming operations during the past two decades has greatly affected the operational management of shrimp farms worldwide. BPT approach promises a healthy rearing system, which is increasingly identified as one possible approach for disease prevention.

As the fish/shrimp ponds are rich in microbial community, the inorganic nitrogen added through the feed can be assimilated by these microorganism and converted into microbial protein through an adjustment of $\mathrm{C}: \mathrm{N}$ ratio. The biofloc principle combines the removal of nutrients from the water with the production of microbial biomass, which can be used by the cultured species in situ as additional food source. The optimum $\mathrm{C}: \mathrm{N}$ ratio in an aquaculture system can be maintained (C:N ratio of 15:1 is optimal for biofloc production) by adding different locally available cheap carbon sources and/or reducing protein percentage in feed. Under optimum $\mathrm{C}: \mathrm{N}$ ratio, inorganic nitrogen is immobilised 
into bacterial cell while organic substrates are metabolised. In a typical brackishwater pond, only $20-25 \%$ of feed protein is utilised by the fish/shrimp, rest of which goes as waste in the form of ammonia and other metabolites, organic $\mathrm{N}$ in faeces and feed residue.

Biofloc technology has recently gained attention as a sustainable method to maintain water quality with the added value of producing proteinaceous feed in situ (Crab et al., 2012). In addition to organic nitrogenous waste, ammonium will be converted into bacterial biomass if $\mathrm{C}: \mathrm{N}$ ratio is balanced at 10-15:1 (Schneider et al., 2005). The cell walls of the microbial constituent of this biofloc, such as bacterial lipopolysaccharide, peptidoglycan and $\beta-1,3$-glucans, stimulate nonspecific immunity of fish/shrimp (Panigrahi et al., 2007, 2009). The growth rate and microbial biomass yield per unit substrate of heterotrophs are higher than that of nitrifying bacteria, thus making many folds increase in heterotrophic bacteria (Hargreaves, 2006). Several studies including that of ours (Arnold et al., 2009; Panigrahi et al., 2014) indicated that biofloc with periphyton systems increased growth, survival and protective response, while also contributing to more favourable water quality.

As BPT promises a healthy rearing system, it is increasingly identified as one possible solution for disease problems especially for diseases striking at early stages (early mortality syndrome (EMS)/acute hepatopancreatic necrosis disease (AHPND) through introduction of biofloc based nursery phases. However, many questions remain unanswered regarding biofloc based mechanisms of antibacterial/antiviral immune responses in penaeid shrimp. The purpose of this study was to evaluate the effect of biofloc and periphyton technology (BPT) on growth and immunomodulatory performance of Pacific white shrimp Penaeus vannamei during nursery and grow-out culture.

\section{Materials and methods}

\section{Experimental design}

A 130 days experiment was conducted using juveniles of P. vannamei during April, 2014 to July, 2014 at Muthukadu Experimental Station, ICAR-Central Institute of Brackishwater Aquaculture (ICAR-CIBA), Chennai, Tamil Nadu, India. The two treatments (Control and BPT) in duplicates were randomly distributed into 4 cement tanks (7.5x1.74x1.1m, $15 \mathrm{~m}^{2}$ bottom area, 150001 capacity,) with 8 compartments. Seawater (previously chlorinated) was filled in all the experimental units. Agricultural lime $\left(\mathrm{CaCO}_{3}\right)$ was applied to all the tanks at $200 \mathrm{~kg} \mathrm{ha}^{-1}$. Tanks were fertilised with inorganic fertilisers, urea $\left(150 \mathrm{~kg} \mathrm{ha}^{-1}\right)$ and single super phosphate, SSP $\left(150 \mathrm{~kg} \mathrm{ha}^{-1}\right)$ on the first day. Inorganic fertilisers were applied initially at 2-3 days intervals in split doses. Biofloc was generated by using a mix of yeast, molasses, probiotics (Bacillus subtilis, $5.4 \times 10^{9} \mathrm{CFU} \mathrm{ml}^{-1}$ ), wheat flour, rice bran and pelleted feed mixed/dissolved in autoclaved seawater (50 1), aerated overnight (24 h) and applied uniformly on the third day in all the treatment tanks for development of autotrophs. C: $\mathrm{N}$ ratio was maintained followed by the method of Avnimelech (1999) for transition in to heterotrophic system.

\section{Experimental diet preparation}

Formulated pellet feed containing $40 \%$ of crude protein were used for supplementary feeding in both control and treatment groups. Details of ingredients and proximate composition of the feed are given in Table 1. The coarse ingredients were powdered in a two stage hammer mill and micropulveriser and then passed through $300 \mu \mathrm{m}$ mesh screen. All the ingredients including liquid ingredients were mixed in a batch mixer as per Table 1 . The mixed mash was pelleted in a Ring-Die pellet mill at $16 \%$ moisture, at $95^{\circ} \mathrm{C}$ under steam conditioning.

\section{Biofloc management, shrimp stocking and feeding}

Out of the 8 cement compartments, 2 tanks were stocked with juvenile $P$. vannamei $(1.48 \pm 0.4 \mathrm{~g})$ at a density of 150 nos. $\mathrm{m}^{-3}$. Daily feeding started at $10 \%$ of body weight, which was gradually reduced to $3 \%$ by the end of experiment. The

Table 1. Ingredient and proximate composition (as \% fed basis) of test diets

\begin{tabular}{ll}
\hline Ingredient & Feed (Control, BPT) \\
\hline Protein base $^{1}$ & 70 \\
Carbohydrate base $^{2}$ & 24 \\
Fish oil & 2 \\
Lecithin & 1 \\
Vitamin and mineral mix $^{3}$ & 2 \\
Binder $^{4}$ & 1 \\
\hline Proximate composition & \\
\hline Moisture & 9.49 \\
Crude protein & 39.56 \\
Ether extract & 6.72 \\
Crude fibre & 3.52 \\
Total ash & 12.42 \\
NFE & 28.29 \\
\hline
\end{tabular}

${ }^{1}$ Protein base: Fish meal: Acetes sp.: Soya cake: Gingelly oil cake in the ratio $4: 2: 3: 1$

${ }^{2}$ Carbohydrate base: Wheat: Broken rice: Maida in the ratio 4:2:3

${ }^{3}$ Vitamins $\left(\mathrm{mg} \mathrm{kg}^{-1}\right)$ : Vitamin A 20.0, Vitamin D 4.0, Vitamin E 120.0, Vitamin K 60.0, Choline chloride 6000.0, Thiamine 180.0, Riboflavin 240.0, Pyridoxine 180.0, Niacin 1080.0, Pantothenic acid 720.0, Biotin 2.0, Folic acid 30.0, Vitamin B12 0.150 Inositol 1500.0, Vitamin C 9000.0. Minerals $\left(\mathrm{g} \mathrm{kg}^{-1}\right)$ : $\mathrm{CaCO}_{3} 28.0, \mathrm{~K}_{2} \mathrm{SO}_{4} 10.0, \mathrm{MgSO}_{4}$ 12.5, $\mathrm{CuSO}_{4} 0.2, \mathrm{FeCl}_{3} 0.5, \mathrm{MnSO}_{4} 0.5, \mathrm{KI} 0.01 ; \mathrm{ZnSO}_{4} 1.0, \mathrm{CoSO}_{4} 0.01$, $\mathrm{Cr}_{2} \mathrm{SO}_{4} 0.05$, Bread flour 7.14

${ }^{4}$ Poly Methylol Carbamide.

${ }^{5}$ Nitrogen free extract calculated by difference $=100$ - $($ moisture $\%+$ Crude protein $\%+$ Crude fibre $\%+$ Ether extract $\%+$ Total ash $\%$ ) 
shrimp were fed with crumbles of 500-800 $\mu$ during the first 15 days followed by $1.8 \mathrm{~mm}$ pellets and in the last 30 days with $2.0 \mathrm{~mm}$ pellets. Feed was distributed equally to shrimps in all the experimental units, thrice daily at 0600,1100 and $1800 \mathrm{hrs}$ initially for 2 months followed by one additional feeding ration at $2200 \mathrm{hrs}$ up to harvest. A uniform feeding regime was followed for direct comparison of water quality parameters and microbial dynamics in the experimental tanks. The feeding ration were calculated based on the shrimp biomass in the treatments.

Pre-weighed molasses was mixed in a beaker and uniformly distributed over the tank surface directly after feed application at 1100 and $1800 \mathrm{hrs}$. Since molasses contained $28 \%$ carbon, $1.0 \mathrm{~g}$ molasses was added for each $1.0 \mathrm{~g}$ of feed in the experimental groups. To increase the $\mathrm{C}: \mathrm{N}$ ratio to $10: 1$, molasses was added assuming that $10 \mathrm{~g}$ of carbon is required to convert $1 \mathrm{~g}$ of total ammonia nitrogen, generated from excreta and uneaten feed, into bacterial biomass (Avnimelech, 1999). Continuous aeration and agitation was provided employing one $5 \mathrm{hp}$ blower passing through sand stones aerator, fixed $10 \mathrm{~cm}$ above the soil bottom layer, with capacity of $7.5 \mathrm{~m}^{3}$ air per tank per min. In the biofloc treatment tanks, minimal water exchange principle was followed throughout the experimental period.

\section{Proximate composition of experimental diets}

The proximate composition of experimental diet was determined following the standard methods of AOAC (1995). The moisture content was determined by drying at $105^{\circ} \mathrm{C}$ to a constant weight and the difference in weight of the sample indicated the moisture content. Nitrogen content was estimated by Kjeldahl (Kelplus, DXVA, Pelican equipments, India) method and crude protein was calculated by multiplying nitrogen percentage by 6.25 . Crude lipid was determined by the solvent extraction method by Soxtec system (Soxtec system, SCS-6, Pelican equipments, India) using diethyl ether (boiling point, $40-60^{\circ} \mathrm{C}$ ) as a solvent. Ash content was determined by incinerating the samples in a muffle furnace at $600^{\circ} \mathrm{C}$ for $6 \mathrm{~h}$. Crude fiber was determined based on the weight loss on ignition of the oven dried residue remaining after sequential digestion of a sample with $\mathrm{H}_{2} \mathrm{SO}_{4}$ and $\mathrm{NaOH}$ solution using Fibertec (Foss Tecator 2022, Sweden). Gross energy was determined as per NRC (1993). Total nitrogen free extract (NFE) was determined according to Hastings and Dupree (1969).

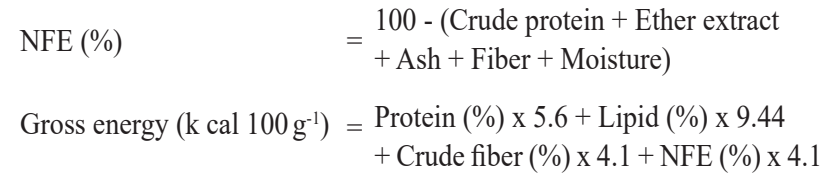

\section{Assessment of water quality parameters}

Water quality of the experimental systems was checked at weekly intervals at $0900 \mathrm{hrs}$. Water parameters such as temperature (mercury thermometer), $\mathrm{pH}$ (pH-Scan-Eutech instruments, Singapore), salinity (hand refractometer), total ammonia nitrogen, TAN (Phenol hypochlorite method), $\mathrm{NO}_{2}-\mathrm{N}, \mathrm{NO}_{3}-\mathrm{N}$, phosphate- $\mathrm{P}\left(\mathrm{PO}_{4}-\mathrm{P}\right)$, total alkalinity, turbidity and dissolved oxygen were analysed following APHA (1998). Total suspended solid (TSS) was determined every fifteen days' interval (APHA, 1998). Biofloc volume was quantified employing Imhoff cone on daily basis to understand the dynamics of biofloc generation and to adopt control measures in case of excess biofloc generation if any.

\section{Estimation of microbial biomass}

Total heterotrophic bacterial count and Vibrio count of water and soil samples were determined at 10 days interval up to 130 days of the experiment. Water samples were collected in sterile poly-propylene bottles from the centre of the tank. The samples were maintained at $4^{\circ} \mathrm{C}$ and immediately brought to the laboratory. Two hundred $\mathrm{ml}$ of water sample was homogenised in a kitchen blender at $12000 \mathrm{rpm}$ for 30 sec. Subsequently, tenfold serial dilution was made in normal saline solution (NSS) and $0.1 \mathrm{ml}$ of appropriate dilutions were plated in duplicates on Zobell marine agar containing $1 \% \mathrm{NaCl}(\mathrm{w} / \mathrm{v})$ for total count and on thiosulfate citrate bile salts sucrose agar (TCBS agar) for Vibrio count. Plates were incubated at room temperature for $48 \mathrm{~h}$ and colony in the range of 30 to 300 were counted and expressed as bacterial colony forming unit (cfu).

\section{Estimation of growth and production parameters}

The growth performance was assessed in terms of length gain $(\mathrm{mm})$, average weight gain $(\mathrm{AWG})\left(\mathrm{g}\right.$ week $\left.{ }^{-1}\right)$, final biomass $\left(\mathrm{g} \mathrm{m}^{-3}\right)$, survival (\%) and specific growth rate (SGR), whereas, feed conversion ratio (FCR) and protein efficiency ratio (PER) were recorded to assess shrimp performance in terms of feed utilisation. All the shrimps were sampled thrice a month for measuring the above parameters. At the end of the experiment, the above mentioned indicators were estimated in addition to final yield $\left(\mathrm{kg} \mathrm{ha}^{-1}\right)$. The growth parameters were calculated using the following formulae:

\begin{tabular}{|c|c|c|}
\hline Weight gain (\%) & $=$ & $\frac{\text { Final weight }(\mathrm{g}) \text { - Initial weight }(\mathrm{g})}{\text { Initial weight }(\mathrm{mg})} \times 100$ \\
\hline Length gain $(\%)$ & $=$ & $\begin{array}{l}\text { Final length }(\mathrm{mm}) \text { - Initial length }(\mathrm{mm}) \\
\text { Initial length }(\mathrm{mm}) \times 100\end{array}$ \\
\hline $\begin{array}{l}\text { Specific growth rate } \\
\text { (SGR) }(\%)\end{array}$ & $=$ & $\begin{array}{l}\text { (ln final weight - } \ln \text { initial weight)/Days } \\
\text { of culture x } 100\end{array}$ \\
\hline $\begin{array}{l}\text { Average daily } \\
\text { growth (ADG) } \\
\left(\text { mg day }^{-1}\right)\end{array}$ & $=$ & $\frac{\text { Final weight }(\mathrm{mg}) \text { - Initial weight }(\mathrm{mg})}{\text { Experimental duration (days) }}$ \\
\hline
\end{tabular}




$\begin{array}{ll}\text { Survival (\%) } & =\frac{\text { Shrimp no. at the end of experiment } \mathrm{x} 100}{\text { Shrimp no. at the beginning of experiment }} \\ \text { FCR } & =\text { Feed applied/Body weight gain } \\ \text { FER } & =\text { Weight gain/Feed intake } \\ \text { PER } & =\text { Net weight gain/Protein in feed applied }\end{array}$

Immune parameters

The haemolymph from sampled shrimp was collected using a $2 \mathrm{ml}$ syringe $(21 \mathrm{G})$ with or with out anticoagulant saline, from the ventral sinus of the first abdominal segment, as per the methodology for the required immune parameters. The anticoagulant saline solution was prepared by mixing $\mathrm{NaCl}$ (340 mm), KCl (13 mm), MgSO4 (11 mm), MgCl2 (10 $\mathrm{mm}), \mathrm{NaH} 2 \mathrm{PO} 4(0.3 \mathrm{~mm})$ and glucose $(1.6 \mathrm{~mm})$ in $100 \mathrm{ml}$ distilled water , $\mathrm{pH}$ of the solution was adjusted to 7.8 using $\mathrm{NaHCO}$. The haemocytes count was carried out as per the methodology of Wootten et al. (2003) and Soderhall (1982). Similarly phenoloxidase activity was determined as per the methods of Soderhall and Cerenius(1992).

\section{Challenge trial}

Experimental infection was carried out with permission from the Ethical Committee for Animal Experiments of ICAR-CIBA, followingand the guidelines of OIE was followed. The biofloc treated and control intermoult shrimps of 12-15 g ABW were stocked into 1001 FRP tanks, with 20 animals in each tank in triplicate. The levels of $\mathrm{pH}$, salinity and oxygen were maintained at optimum levels and the biofloc environment was maintained. A pathogenic strain of Vibrio parahaemolyticus (MTCC 451) sourced from the Institute of mMicrobial Type culture collections (IMTCC), Chandigarh, India was cultured overnight in Zobell marine broth 2216 (Himedia, India). Twenty millilitre $\mathrm{ml}$ of a suspension of $V$. parahaemolyticus containing $1.21 \times 10^{8}$ cells $\mathrm{ml}^{-1}$. were introduced into the tank. All the shrimps were closely monitored following experimental infection for mortality. No water was exchanged during the experimental trial. During challenge tests, water quality parameters, shrimp survival and cumulative numbers of dead shrimps were recorded every day.

\section{Statistical analysis}

The data were statistically analysed by statistical package SPSS version 17.0 (SPSS Inc., Chicago, IL, USA). Before all analysis data were analysed for normality by probability plots and Kolmogorov-Smirnrov test and for homogeneity of variances by Levene's test. One way ANOVA was used to determine the significance of each parameter among different treatments. If a main effect was significant, the ANOVA was followed by Tukey's test. Level of significance was determined at 99 and $95 \%$ probability levels.

\section{Results}

Water quality parameters

The water quality parameters of the experimental tanks recorded during the study are presented in Table 2. Temperature and salinity in the experimental tanks ranged from $28.5-31.2^{\circ} \mathrm{C}$ and $28-30 \mathrm{ppt}$, respectively during the study period. Biofloc treatments showed significant effect $(\mathrm{p}<0.01)$ on $\mathrm{pH}$ reduction irrespective of protein level in feed. Alkalinity during the entire culture period showed nonsignificant reduction $(\mathrm{p}>0.05)$ in BPT $(18.03 \pm 1.89 \%)$ than control group. There was a significant decrease $(\mathrm{p}<0.05)$ in the ammonia concentration in the BPT groups $(0.313 \pm 0.05)$ with molasses supplementation compared to the convectional group $(0.743 \pm 0.02)$. Carbohydrate supplementation significantly $(\mathrm{p}<0.05)$ reduced TAN levels in BPT group $(42.09 \pm 5.3 \%)$ when compared to that of control group. The mean value of TAN and nitrite at 15 days interval are given in Fig. 1 and 2, respectively.

Similarly, nitrite-N, nitrate-N values were significantly reduced in biofloc with periphyton groups and were

Table 2. Water quality parameters of bio-floc based shrimp culture and control groups he means with no superscript letter in common per factor indicate significant difference

\begin{tabular}{lll}
\hline Parameters & Control & BPT- 40 \\
\hline TAN $(p p m)$ & $0.743 \pm 0.02^{\mathrm{a}}$ & $0.313 \pm 0.05^{\mathrm{b}}$ \\
$\mathrm{NO}_{2}-\mathrm{N}(\mathrm{ppm})$ & $0.504 \pm 0.02^{\mathrm{a}}$ & $0.140 \pm 0.02^{\mathrm{b}}$ \\
$\mathrm{NO}_{3}-\mathrm{N}(\mathrm{ppm})$ & $0.294 \pm 0.10^{\mathrm{a}}$ & $0.204 \pm 0.05^{\mathrm{b}}$ \\
$\mathrm{PO}_{4}^{-\mathrm{P}}(\mathrm{ppm})$ & $0.158 \pm 0.09^{\mathrm{a}}$ & $0.231 \pm 0.13^{\mathrm{b}}$ \\
Alkalinity (ppm) & $197.0 \pm 7.8^{\mathrm{b}}$ & $168.8 \pm 4.6^{\mathrm{a}}$ \\
Floc volume (ml) & $5.13 \pm 1.2^{\mathrm{a}}$ & $18.6 \pm 2.2^{\mathrm{b}}$ \\
TSS (ppm) & $167.9 \pm 3.3^{\mathrm{a}}$ & $575.8 \pm 3.9^{\mathrm{b}}$ \\
Turbidity (NTU) & $16.67 \pm 2.58^{\mathrm{a}}$ & $26.98 \pm 3.68^{\mathrm{b}}$ \\
\hline
\end{tabular}

Each value represents mean \pm S.D. Values in the same row with different superscripts are significantly different $(\mathrm{p}<0.05)$.

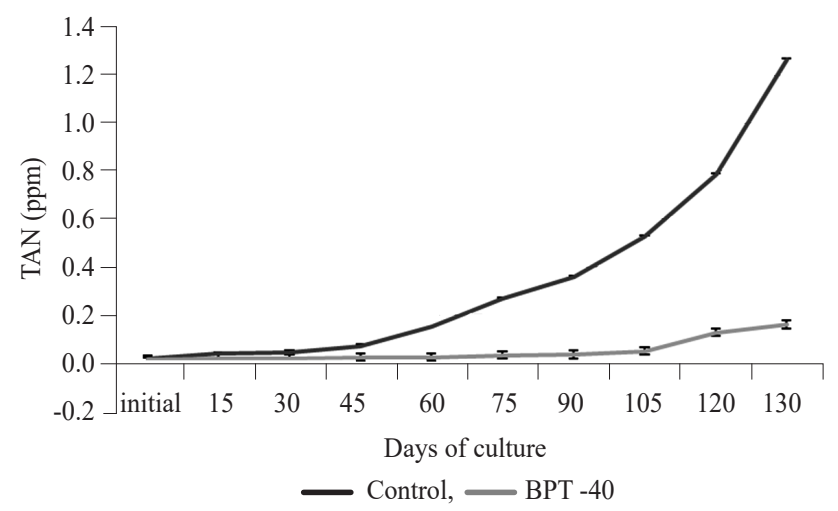

Fig. 1. Mean values of TAN in 15 days time intervals of control and biofloc tanks 


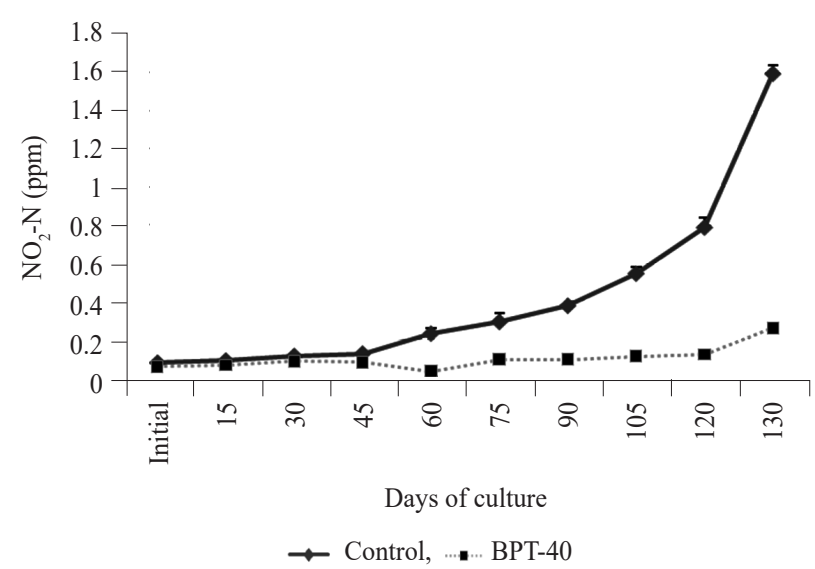

Fig. 2. Nitrite-N levels in control and biofloc based shrimp culture water during 130 days of culture

$34.05 \pm 2.2 \%$ and $40.5 \pm 9.6 \%$, respectively. But, Phosphatephosphorous level was found to be more in BPT treatments (43.4 $\pm 4.4 \%)$ compared to that of the control group.

\section{Quantitative analysis of biofloc}

Microscopic observation of bio-floc revealed that it comprised certain particulate and flocculated microbes, rotifers, copepods; microalgae, protozoan communities like ciliates and detritus. The quantity of biofloc developed was measured using Imhoff flask in terms of turbidity and is presented as monthly average in Table 2. In BPT system with carbohydrate supplementation, turbidity $(26.98 \pm 3.68$ NTU) was significantly higher $(\mathrm{p}<0.05)$ compared to control group (16.67 \pm 2.58 NTU). Similarly, supplementation of molasses resulted in significantly higher total suspended solids (TSS) in BPT $(74.7 \pm 5.0 \%)$ when compared to that of control group (Fig. 3). Bio-floc volume was significantly $(\mathrm{p}<0.05)$ higher in BPT $(18.75 \pm 3.9 \mathrm{ml})$ tanks compared to control $(5.13 \pm 1.2 \mathrm{ml})$ (Fig. 4).

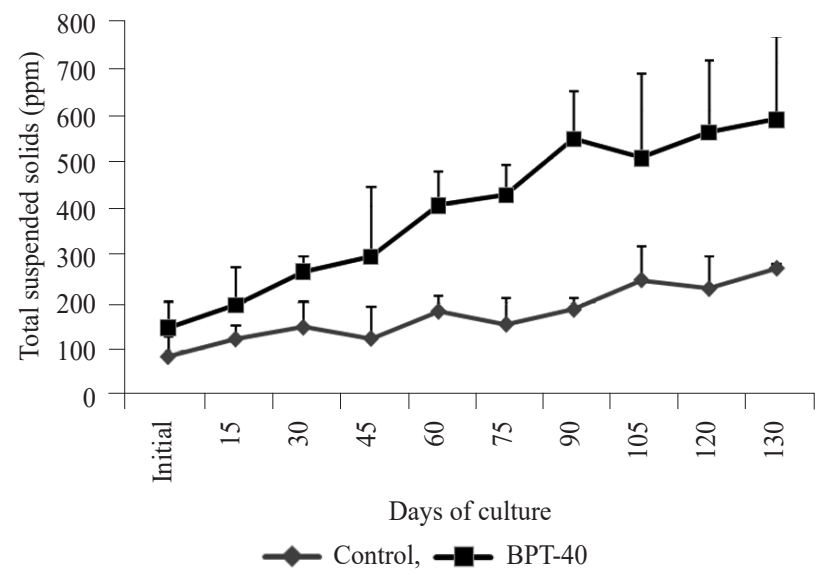

Fig. 3. Total suspended solids (TSS) in control and biofloc based shrimp culture water samples during the experimental period

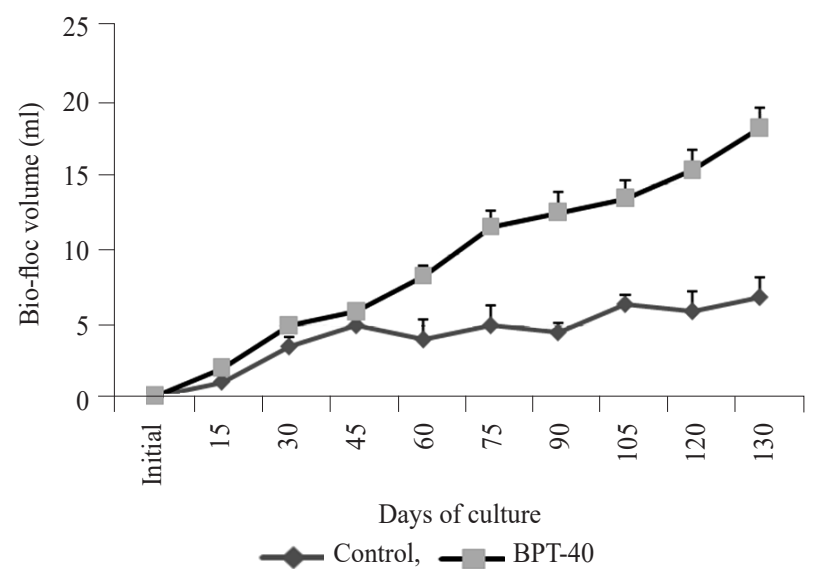

Fig. 4. Biofloc volume in the control and BPT based shrimp rearing system during the experimental period

Microbial analysis

Carbohydrate supplementation significantly increased the total heterotrophic bacterial (THB) count of water in BPT $(82.9 \pm 4.4 \%)$ system as compared with control groups. As the culture progressed, the increasing biomass had significant effect $(\mathrm{p}<0.01)$ over total microbial load with higher levels recorded in BPT compared with control. Similarly, carbohydrate supplementation had significant effect on total Vibrio count (TVC) in water $(\mathrm{p}<0.01)$. TVC levels were greatly reduced in BPT water $(91.80 \pm 0.3 \%)$ whereas in control group, it was higher. The carbohydrate supplementation resulted in increase of total plate count (TPC, $71.7 \pm 3.3 \%$ ) in water of BPT groups. The proportion of Vibrio count to total heterotrophic bacterial count $(\mathrm{V} / \mathrm{T})$ was lower in the biofloc groups compared to that of the control group. In spite of increase in Vibrio load, the V/T ratio was non-significantly $(\mathrm{p}>0.05)$ lower in the BPT groups. The V/T ratio was lower in the BPT water $(11.2 \pm 1.2 \%)$ as compared to that of control $(96.5 \pm 12.8 \%)$.

\section{Growth performance}

The data on growth performance of BPT and control groups is presented in Table 3. The average body weight was significantly $(\mathrm{p}<0.01)$ higher in the bio-floc treated groups (38.15 \pm 3.36$)$ when compared to control group (29.91 \pm 3.58$)$ (Fig. 5).

The improvement in average body weight in the biofloc group was $27.57 \%$ over the control group. The survival rate of the BPT group $(84.13 \pm 0.1 \%)$ was also significantly higher $(p<0.05)$ compared to that of the control group $(70.31 \pm 0.1 \%)$ registering an improvement of $19.6 \%$. Production in the biofloc treatments $\left(43.4 \pm 19.6 \mathrm{t} \mathrm{ha}^{-1}\right)$ was significantly higher compared to that of the control (28.42 $\left.\pm 1.2 \mathrm{t} \mathrm{ha}^{-1}\right)$ (Table 3). BPT groups also showed a significant increase (32.6 to $52.6 \%$ ) in productivity when compared with that of the 
Table 3. Growth performance including weight gain, FER and PER of shrimp

\begin{tabular}{llll}
\hline Treatments & Control & BPT & Significance \\
\hline Initial weight $(\mathrm{g})$ & $1.91 \pm 0.48^{\mathrm{a}}$ & $2.41 \pm 0.59^{\mathrm{b}}$ & $* *$ \\
Final weight $(\mathrm{g})$ & $29.91 \pm 3.58^{\mathrm{a}}$ & $38.15 \pm 3.66^{\mathrm{b}}$ & $* *$ \\
Weight gain $(\mathrm{g})$ & $17.49^{\mathrm{a}}$ & $22.34^{\mathrm{b}}$ & $*$ \\
Survival rate $(\%)$ & $70.31 \pm 3.3^{\mathrm{a}}$ & $84.13 \pm 3.86^{\mathrm{b}}$ & $*$ \\
SGR $(\%)$ & $2.11^{\mathrm{a}}$ & $2.13^{\mathrm{b}}$ & $*$ \\
FCR & $2.07^{\mathrm{a}}$ & $1.58^{\mathrm{b}}$ & $*$ \\
FER & $0.48^{\mathrm{a}}$ & $0.63^{\mathrm{b}}$ & $*$ \\
PER & $1.21^{\mathrm{a}}$ & $1.58^{\mathrm{b}}$ & $* *$ \\
Productivity $\left(\mathrm{t} \mathrm{ha}^{-1}\right)$ & $28.42 \pm 1.2^{\mathrm{a}}$ & $43.4 \pm 19.6^{\mathrm{b}}$ & $*$
\end{tabular}

Each value represents mean \pm S.D. Values in the same row with different superscripts are significantly different $(\mathrm{p}<0.05)$

"significant at $\mathrm{p}<0.05 ;{ }^{* *}$ significant at $\mathrm{p}<0.01$

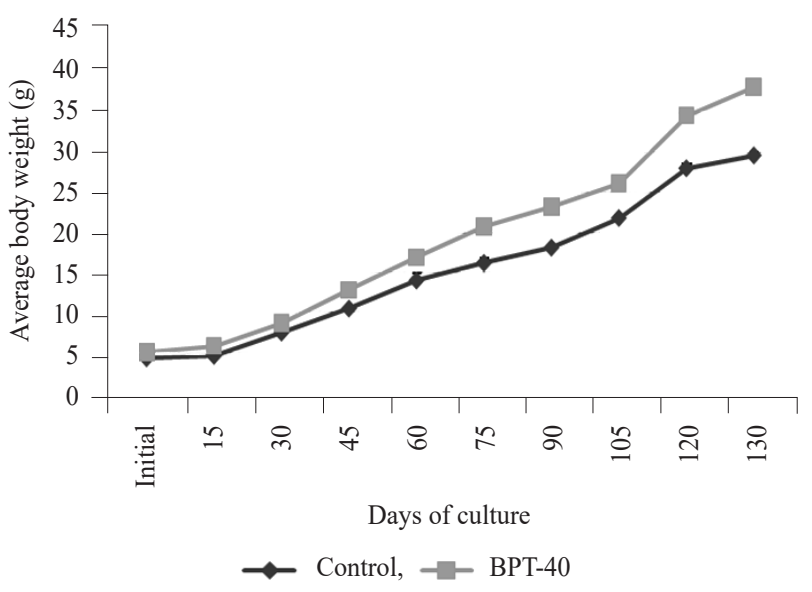

Fig. 5. Mean values of ABW in control and BPT based shrimp culture system

control non-biofloc group. The FCR recorded in the group $(1.58 \pm 0.2)$ was lower compared to control group (2.07 \pm 0.2$)$. There is an improvement of 10 to $31 \%$ as reflected in the declining FCR in the biofloc group. Similarly, higher PER and FER of $1.58 \pm 0.15$ and $0.63 \pm 0.12$ respectively were observed in BPT compared to control group $(1.21 \pm 0.4$ and $0.48 \pm 0.10$ respectively). The proximate composition of shrimps from the two experimental groups are presented in Table 4.

\section{Immunological parameters and challenge trial}

Total haemocyte count was significantly $(p<0.05)$ higher in BPT reared shrimps $\left(17.7 \pm 1.4 \times 10^{6}\right.$ cells $\left.\mathrm{ml}^{-1}\right)$ when compared to control $\left(7.1 \pm 0.75 \times 10^{6}\right.$ cells ml$\left.^{-1}\right)$ (Fig. 6).

Serum phenoloxidase activity (Fig. 7) was found higher in the BPT treated shrimps $\left(0.146 \pm 0.009\right.$ units min $^{-1}$ $\left.\mathrm{mg} \operatorname{protein}^{-1}\right)$ compared to control shrimps $(0.051 \pm 0.003$

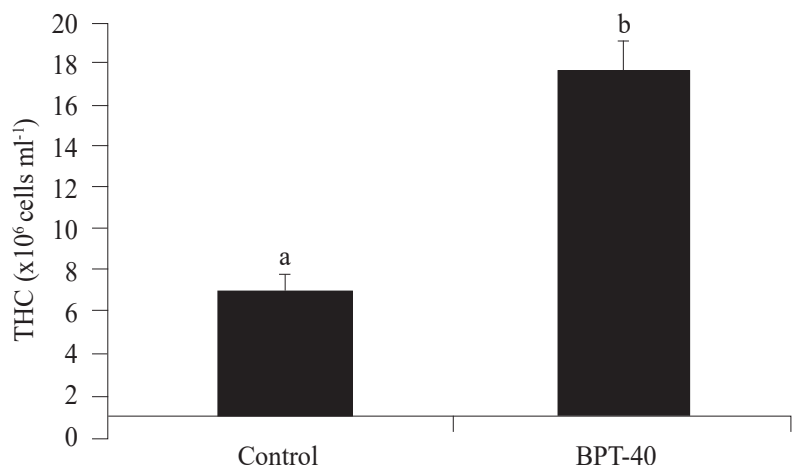

Fig. 6. Total haemocyte count of BPT and control group shrimps $(\mathrm{n}=10)$. Error bars represent mean $\pm \mathrm{SE}$

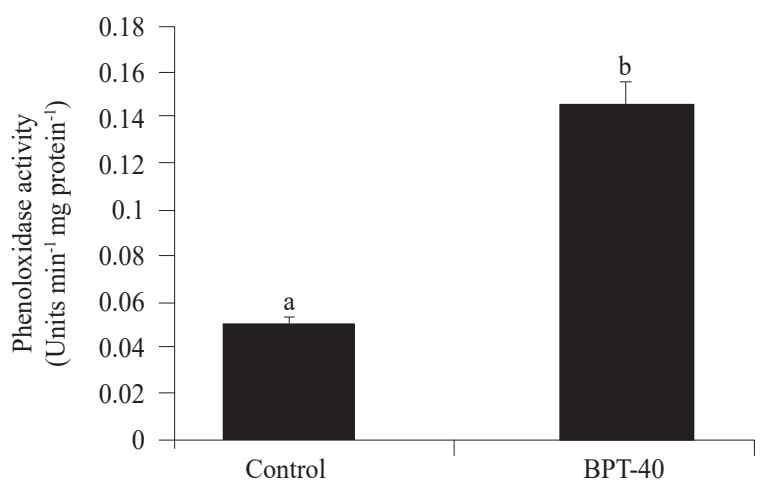

Fig. 7. Serum phenoloxidase activity ofBPT and conventional reared shrimp $(n=20)$. Error bars represent mean \pm SE

units $\min ^{-1} \mathrm{mg}$ protein $\left.{ }^{-1}\right)$. Cumulative percent mortality of conventionally grown shrimps was significantly higher than the BPT group (Fig. 8) when challenged with V. parahaemolyticus.

Table 4. Proximate composition (\%) of P. vannamei (as \% wet weight basis) cultured in the BPT and non-BPT systems

\begin{tabular}{lllllll}
\hline Treatment group & Moisture & Crude protein & Ether extract & Crude fibre & Total ash & NFE $^{*}$ \\
\hline Control & $76.38 \pm 0.94$ & $16.40 \pm 0.37$ & $1.06 \pm 0.02$ & $1.37 \pm 0.12$ & $2.61 \pm 0.15$ & $2.18 \pm .93$ \\
BPT & $77.18 \pm 1.32$ & $16.55 \pm 0.12$ & $1.08 \pm 0.06$ & $1.42 \pm 0.17$ & $2.53 \pm 0.14$ & $1.24 \pm 1.39$ \\
\hline
\end{tabular}

"Nitrogen free extract $=100-($ moisture $\%+$ Crude protein $\%+$ Crude fibre $\%+$ Ether extract $\%+$ Total ash $\%)$ 


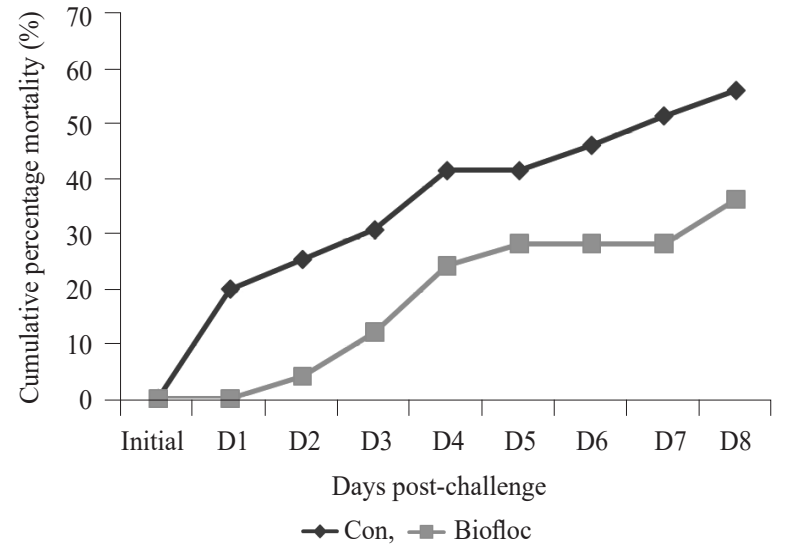

Fig. 8. Cumulative mortality recorded for BPT and conventionally grown shrimps following challenge with $V$. parahaemolyticus

The challenge trial revealed that the mortality rate was higher in conventionally grown shrimps than those reared in BPT based systems. Mortality of $57.9 \%$ was recorded in challenged control shrimps but a significantly lower mortality of $37.5 \%$ was observed in shrimps reared in biofloc based systems, eight days post - challenge.

\section{Discussion}

Water quality parameters play an important role in aquaculture. The temperature and salinity which are important parameters (Chen et al., 1990, Hariati et al., 1996), did not vary significantly in the treatments in the present study. The TAN level was observed to be higher in the control tanks as compared to the treatment tanks. The findings are in agreement with Hari et al. (2004); Avnimelech and Mokady (1988); Avnimelech et al. (1989) and Avnimelech (1999) who reported that addition of carbohydrate to the production systems reduces the TAN concentration through immobilisation by bacterial biomass. It has been reported that fish in a pond assimilate only $15-30 \%$ of the nitrogen added in the feed (Acosta-Nassar et al., 1994; Gross et al., 2000; Davenport et al., 2003), the remainder being lost to the system as ammonia and organic $\mathrm{N}$ in faeces and feed residue, which also undergoes decomposition and eventually produces ammonia. Therefore, higher dietary protein levels lead to significantly higher TAN and $\mathrm{NO}_{2}-\mathrm{N}$ concentrations in the water column. Li and Lovell (1992) reported that the ammonia concentration increased with increasing dietary protein concentration and protein feeding rate. Similarly, in this experiment, TAN, $\mathrm{NO}_{2}-\mathrm{N}$ and $\mathrm{NO}_{3}-\mathrm{N}$ levels decreased in the biofloc treated tanks because of the addition of carbon sources whereas control tanks recorded comparatively high values. Also, it was reported earlier that zero water exchange ponds using carbon enable to control the accumulation of inorganic nitrogen through a balanced ratio of carbon to nitrogen of the feed (Avnimelech et al., 1989, 1992, 1994; Avnimelech, 1998, 1999). In addition, Stuart et al. (2009) raised tiger shrimp $P$. monodon in zero water exchange model using a daily carbon source (tapioca powder) to promote the microbial community and improve water quality. Xu et al. (2015) reported that abundance of algae and heterotrophic bacterial population increase phosphate content in the biofloc treatment groups. In the present study, total phosphate was significantly higher in BPT compared to control. According to Jarrett et al. (1993), high primary production would lead to decline in alkalinity. Thus, maintenance of optimum alkalinity through liming is very important since calcium is also crucial for shrimp growth and moulting (Tseng, 2009). Our study revealed that the total alkalinity levels were significantly low in the BPT groups than control. Furthermore, present study revealed that the levels of TSS, turbidity and biofloc volume showed significant difference between BPT and control groups. This can be converted from feed (protein as nitrogen) and carbon source, which subsequently increased bacterial/ microbial population in the biofloc systems (Huchette et al., 2000; Azim, 2001).

In the biofloc, organic matter, zooplankton communities like ciliates, rotifers, copepods and a small amount of autotrophic microalgae were noticed during the present study. Similarly, Ballester et al. (2010) reported that biofloc is composed of attached heterotrophic bacteria, filamentous cyanobacteria, dinoflagellates, ciliates, flagellates and rotifers. Various factors like salinity, light and type of culture system affects the microbial composition of biofloc. For example, Ju et al. (2008a) reported the dominance of algal communities over bacterial biomass in flocs collected from outdoor shrimp culture units. Lower dominance of autotrophic community noticed in the present study might be due to lack of direct sunlight in the biofloc indoor production facility (Shyne Anand et al., 2014).

Many studies have demonstrated beneficial effects of biofloc on shrimp culture (Wasielesky et al., 2006; Ballester et al., 2010; Ray et al., 2011; Haslun et al., 2012; Xu and Pan, 2012; Zhao et al., 2012). Several researchers suggested that apart from maintaining good and stable water quality, the established biofloc in the culture system can improve growth performance and feed utilisation of different shrimp species viz., P. monodon (Arnold et al., 2009), P. semisulcatus (Megahed, 2010), Farfantepenaeus paulensis (Ballester et al., 2010), P. vannamei (Xu and Pan, 2012) and Marsupenaeus japonicus (Zhao et al., 2012).

Survival rate was significantly higher in biofloc treatments compared to control, indicating no increased stress due to the presence of biofloc (Megahed et al., 2014). Higher survival and improved growth of the shrimp in all the biofloc treatments (Xu and Pan, 2012) can also, in turn, support the view that the shrimp grew in a healthy condition in bioflocbased tanks with carbohydrate addition. 
The presence of biofloc helped to improve shrimp growth, survival rate and the culture productivity in the present study. The findings corroborate the results of other studies that show the positive effect of biofloc on production indices for the culture of post-larvae and juvenile shrimp (Arnold et al., 2009; Audelo-Naranjo et al., 2010; Lezama-Cervantes and Paniagua-Michel, 2010; Zhang, 2011; Viau et al., 2012). Reduction of dietary protein level without affecting growth performance of cultured shrimp in the presence of biofloc has been reported by several authors (Hari et al., 2004; Ballester et al., 2010). This is in accordance with earlier investigation by several authors (Arnold et al., 2009; Asaduzzaman et al., 2009,2010 ) which revealed that the growth was significantly greater when carbon was applied in shrimp culture ponds with zero water exchange model. Inclusion of biofloc as a dietary ingredient in shrimp diet was found to improve the growth performance of $P$. vannamei (Ju et al., 2008b; Kuhn et al., 2009, 2010).

The present study revealed that the total heterotrophic bacterial counts was significantly higher in the BPT tank water as compared to control tanks. Appropriate carbohydrate addition could result in heterotrophic bacteria effectively assimilating the TAN and $\mathrm{NO}_{2}-\mathrm{N}$ to synthesise bacterial protein and new cells (Kirchman and Keil, 1990; Avnimelech, 1999; Touratier et al., 1999; Wang and Yin, 2009). Similar results were also found in Macrobrachium. rosenbergii culture system by Asaduzzaman et al. (2008). Massive bioflocs resulted from active bacterial metabolism and growth under the carbon addition (Burford et al., 2004; Azim and Little, 2008; Crab et al., 2009) might also provide appropriate substratum for the colonisation and growth of autotrophic as well as heterotrophic bacteria. In BPT system, the vibrio counts were recorded low compared to the control. The study revealed that the application of biofloc inoculum leads to abundance of THB and decreased vibrio load in the treated water. It was also effective in controlling Vibrio population and thus helped to improve water quality and subsequently shrimp health. These findings are similar to the observations made by Ravichandran and Jallaluddin (2000), who used Environ-AC @25 kg ha ${ }^{-1}$ as an initial dosage followed by $10 \mathrm{~kg}$ at weekly interval.

Crustaceans, especially, shrimps lack a specific, adaptive immune system and rely entirely on their innate immune mechanisms that include both cellular and humoral responses for defense against pathogens (Vazquez et al., 2009). The circulating hemocytes play a central role in cellular and humoral immune system (Bachere et al., 2004). The circulating haemocyte count has been considered a functional indicator of immune capability (Rodriguez and Le Moullac, 2000). In the present study, shrimps reared in BPT based system had significantly higher $(p<0.05)$ total haemocyte counts compared to control shrimps.
The pro-phenoloxidase (pro-PO) activating system is an important part of immune response in shrimps, which includes recognition of foreign invaders and nonliving entities, activation of a wide range of defence reactions, such as phagocytosis and antibacterial activity, encapsulation and nodule formation (Soderhall, 1982; Soderhall and Cerenius, 1992). In the present study, serum phenoloxidase (PO) activity was significantly higher in shrimps from BPT based culture compared to control group shrimps. BPT systems induce the activation of the host immune system when the disease causative pathogen is in close proximity. Cumulative percent mortality of conventional and BPT group shrimps challenged with $V$. parahaemolyticus showed significant difference. BPT are often viewed as a mechanism that provides shrimp with pattern recognition that ultimately lead to stimulation of non-specific immune system. It is also hypothesised that the constituents of bacterial cell walls trigger the non-specific immune system in shrimps.

This biofloc based technology as revealed through our studies brings out the advantages like recycling nutrients/organic matter, improving water quality through in situ bioremediation, providing stress-free environment, augmentation of natural food, improvement of growth, immunity and FCR of the cultured shrimps. Improving farm biosecurity by exclusion of pathogens, avoidance of chemotherapeutics, antibiotics with negligible environmental impact are among the other features of this system. Obviously, this upcoming technology will ensure high productivity though a sustainable and environmental friendly approach.

\section{References}

Acosta-Nassar, M. V., Morell, J. M. and Corredor, J. E. 1994. The nitrogen budget of a tropicalsemi-intensive freshwater fish culture pond. J. World Aquac. Soc., 25(2): 261-270.

AOAC. 1995. Official methods of analysis, $15^{\text {th }}$ edn. In: K. Helrich (Ed.), Association of Official Analytical Chemists (15th ed.). Virginia, Washington DC, USA, 1094 pp.

APHA. 1998. Standard methods for the examination of water and wastewater, $20^{\text {th }}$ edn., Washington, DC, $1193 \mathrm{pp}$.

Audelo-Naranjo, J. M., Martinez-Cordova, L. R., Voltolina, D. and Gomez-Jimenez, S. 2010. Water quality, production parameters and nutritional condition of Litopenaeus vannamei (Boone, 1931) grown intensively in zero water exchange mesocosms with artificial substrates. Aquac. Res., 42(9): 1371-1377.

Arnold, S. J, Coman, F. E., Jackson, C. J. and Groves, S. A. 2009. High-intensity, zero water exchange production of juvenile tiger shrimp, Penaeus monodon: an evaluation of artificial substrates and stocking density. Aquaculture, 293: 42-48.

Asaduzzaman, M., Wahab, M. A., Verdegem, M. C. J., Huque, S., Salam, M. A. and Azim, M. 2008. C/N ratio control and substrate addition for periphyton development 
jointly enhance freshwater prawn Macrobrachium rosenbergii production in ponds. Aquaculture, 280: 117-123.

Asaduzzaman, M., Wahab, M. A., Verdegem, M. C. J., Benerjee, S., Akter, T., Hasan, M. M. and Azim, M. E. 2009. Effects of addition of tilapia Oreochromis niloticus and substrates for periphyton developments on pond ecology and production in $\mathrm{C} / \mathrm{N}$-controlled freshwater prawn Macrobrachium rosenbergii farming systems. Aquaculture, 287: $371-380$

Asaduzzaman, M., Rahman, M. M., Azim, M. E., Islam, M. A., Wahab, M. A., Verdegem, M. C. J. and Verreth, J. A. J. 2010. Effects of $\mathrm{C} / \mathrm{N}$ ratio and substrate addition on natural food comunities in freshwater prawn monoculture ponds. Aquaculture, 306: 127-136.

Avnimelech, Y., Mokady, S. and Schroeder, G. L. 1989. Circulated ponds as efficient bioreactors for single-cell protein production. Isr. J. Aquac., Bamidgeh, 41: 58-66.

Avnimelech, Y., Kochva, M. and Diab, S. 1994. Development of controlled intensive aquaculture systems with a limited water exchange and adjusted carbon to nitrogen ratio. Isr. J. Aquac. Bamidgeh, 46: 119-131.

Avnimelech, Y. 1999. C/N ratio as a control element in aquaculture systems. Aquaculture, 176: 227-235.

Avnimelech, Y. and Mokady, S. 1988. Protein biosynthesis in circulated fishponds. In: Pullin, R. S. V., Bhukaswan, T., Tonguthai, K. and Maclean J. L. (Eds.). Proceeding of the second international symposium on tilapia in aquaculture, p. 301-309.

Avnimelech, Y., Diab, S., Kochva, M. and Mokady, S. 1992. Control and utilisation of inorganic nitrogen in intensive fish culture ponds. Aquac. Res., 23: 421-430.

Avnimelech, Y., Mozes, N. and Weber, B. 1992. Effects of aeration and mixing on nitrogen and organic matter transformations in simulated fish ponds. Aquac. Eng., 11: 157-169.

Avnimelech, Y. 1998. Minimal discharge from intensive fish ponds. J. World Aquac. Soc., 29: 32-37.

Azim, M. E., Wahab, M. A., van Dam, A. A., Beveridge, M. C. M., Milstein, A. and Verdegem, M. C. J. 2001. Optimisation of fertilisation rate for maximising periphyton production on artificial substrates and the implications for periphyton-based aquaculture. Aquac. Res., 32: 749-760.

Azim, M. E and Little, D. C. 2008. The biofloc technology (BPT) in indoor tanks: Water quality, biofloc composition, and growth and welfare of Nile tilapia (Oreochromis niloticus). Aquaculture, 283, 29-35.

Bachere, E., Gueguen, Y., Gonzalez, M., Lorgeril, J. De, Garnier, J. and Romestand, B. 2004. Insights into the anti-microbial defense of marine invertebrates: the penaeid shrimps and the oyster Crassostrea gigas. Immunol. Rev., 198: 149-168.

Bradford, M. M. 1976. A rapid and sensitive method for the quantitation of microgram quantities of protein utilising the principle of protein-dye binding. Anal. Biochem., 72: 248-254.
Ballester, E. L. C., Abreu, P. C., Cavalli, R. O., Emerenciano, M., Abreu, L. and Wasielesky, W. 2010. Effect of practical diets with different protein levels on the performance of Farfantepenaeus paulensis juveniles nursed in a zero exchange suspended microbial flocs intensive system. Aquac. Nutr., 16: 163-172.

Burford, M. A., Sellars, M. J., Arnold, S. J., Keys, S. J., Crocos, P. J. and Preston, N. P. 2004. Contribution of the natural biota associated with substrates to the nutritional requirements of the post-larval shrimp Penaeus esculentus (Haswell), in high density rearing systems. Aquac. Res., 35: 508-515.

Crab, R., Kochva, M., Verstraete, W. and Avnimelech, Y. 2009 Bio-flocs technology application in over-wintering of tilapia. Aquac. Eng., 40: 105-112.

Crab, R., Defoirdt, T., Bossier, P. and Verstraete, W. 2012. Biofloc technology in aquaculture: beneficial effects and future challenges. Aquaculture, 356-357: 351-356.

Chen, J. C., Liu, P. C. and Lie, S. C. 1990. Toxicity of ammonia and nitrite to Penaeus monodon adolescents. Aquaculture, 89: $127-137$

Davenport, J., Black, K., Burnell, G., Cross, T., Culloty, S., Ekaratne, S., Furness, B., Mulcahy, M. and Thetmeyer, H. 2003. Aquaculture - The ecological issues. Blackwell Publishing, Oxford.

Gross, A., Boyd, C. E. and Wood, C. W. 2000. Nitrogen transformations and balance in channel catfish ponds. Aquac. Eng., 24: 1-14.

Hariati, A. M., Wiadnya, D. G. R., Tanck, M. W. T., Boon, J. H. and Verdegem, M. C. J. 1996. Penaeus monodon (Fabricius) production related to water quality in East Java, Indonesia. Aquac. Res., 27: 255-260.

Haslun, J., Correia, E., Strychar, K., Morris, T. and Samocha, T. 2012. Characterisation of bioflocs in a no water exchange super-intensive system for the production of food size pacific white shrimp Litopenaeus vannamei. Int. J. Aquac., 2: 29-38.

Hastings, W. and Dupree, H. K. 1969. Formula feeds for channel catfish. Prog. Fish Cult., 31: 187-196.

Hari, B., Kurup, B. M., Varghese, J. T., Schrama, J. W. and Verdegem, M. C. J. 2004. Effects of carbohydrate addition on production in extensive shrimp culture systems. Aquaculture, 241: 179-194.

Hargreaves, J. A. 2006. Photosynthetic suspended-growth systems in aquaculture. Aquac. Eng., 34: 344-363.

Huchette, S. M. H., Beveridge, M. C. M., Baird, D. J. and Ireland, M. 2000. The impact of grazing by tilapias (Oreochromis niloticus L.) on periphyton communities growing on artificial substrate in cages. Aquaculture, 186: $45-60$

Jarrett, J. N., Cutler, M. B., Ebersole, J. P. and Hagar, W. G. 1993. Seasonal variation in $\mathrm{pH}$ and alkalinity and recruitment of sunfish populations. Freshw. Biol., 30: 409-417. 
Jarrett, J. N., M.B. Cutler, M. B., J.P. Ebersole, J. P. and W.G Hagar, W. G. 1993. Seasonal variation in $\mathrm{pH}$ and alkalinity and recruitment of sunfish populations. Freshwater Biol., 30: 409-417.

Ju, Z. Y., Forster, I., Conquest, L. and Dominy, W. 2008a. Enhanced growth effects on shrimp (Litopenaeus vannamei) from inclusion of whole shrimp floc or floc fractions to a formulated diet. Aquac. Nutr., 14: 533-543.

Ju, Z. Y., Forster, I., Conquest, L., Dominy, W., Kuo, W. C. and Horgen, F. D. 2008b. Determination of microbial community structures of shrimp floc cultures by biomarkers and analysis of floc amino acid profiles. Aquac. Res., 39: 118-133.

Kuhn, D. D., Boardman, G. D., Lawrence, A. L., Marsh, L. and Flick, G. J. 2009. Microbial floc meal as a replacement ingredient for fish meal and soybean protein in shrimp feed. Aquaculture, 296: 51-57.

Kirchman, D. L. and Keil, R. G. 1990. Carbon limitation of ammonium uptake by heterotrophic bacteria in the subarctic pacific. Limnol. Oceanogr., 35(6): 1258-1266.

Kuhn, D. D., Lawrence, A. L., Boardman, G. D., Patnaik, S., Marsh, L. and Flick, G. J. Jr. 2010. Evaluation of two types of biofloc derived from biological treatment of fish effluent as feed ingredients for Pacific white shrimp, Litopenaeus vannamei. Aquaculture, 303: 28-33.

Li, M. and Lovell, R. T. 1992. Effect of dietary protein concentration on nitrogenous waste in intensively fed catfish ponds. J. World Aquac. Soc., 23: 122-127.

Lezama-Cervantes, C. and Paniagua-Michel, J. 2010. Effects of constructed microbial mats on water quality and performance of Litopenaeus vannamei post-larvae. Aquac. Eng., 42: 75-81.

Megahed, M. E. 2010. The effect of microbial biofloc on water quality, survival and growth of the green tiger shrimp (Penaeus semisulcatus) fed with different crude protein levels. Arabian J. Aquac., 5(2): 119-142.

Mohamed, M. E. and Mohamed, K. 2014. Sustainable growth of shrimp aquaculture through biofloc production as alternative to fishmeal in shrimp feeds. J. Agric. Sci., 6(6): 176-188.

Moss, K. R. K. and Moss, S. M. 2004. Effects of artificial substrate and stocking density on the nursery production of pacific white shrimp Litopenaeus vannamei. J. World Aquac. Soc., 35: 536-542.

NRC 1993. Nutrient requirements of fish. National Research Council, National Academy Press, Washington DC, USA.

Panigrahi, A., Kiron, V., Satoh, S., Hirono, I., Kobayashi, T., Aoki, T., Puangkaew, J. and Sugita, H. 2007. Immunomodulation and expression of immune related genes in rainbow trout Oncorhynchus mykiss fed probiotic-supplemented diets. Dev. Comp. Immunol., 31: 372-382.

Panigrahi, A., Azad, I. S., Das, B. K., Dandpat, J., Das, G., Behera, S. and Mishra, S. S. 2009. Probiotic induced immunomodulation: investigation into the cellular and molecular mechanism involved. Res. J. Biotechnol., 4(3): 7-13.
Panigrahi, A., Sundaram, M., Ravichandran, P. and Gopal, C. 2014. Microbial soup - Eco based approach for shrimp culture and management. ENVIS Newsletter, 12(2): 3-6.

Ray, A. J., Dillon, K. S. and Lotz, J. M. 2011. Water quality dynamics and shrimp (Litopenaeus vannamei) production in intensive, mesohaline culture systems with two levels of biofloc management. Aquac. Eng., 45: 127-136.

Ravichandran, R. and Jalaluddin, R. S. 2000. Stress management strategy with probiotics for preventing shrimp diseases. Proceedings of the First Indian Fisheries Science Congress, 21-23 September, 2000, Chandigarh, India 112 pp.

Rodriguez, J. and Moullac, G. Le. 2000. State of the art of immunological tools and health control of penaeid shrimp. Aquaculture, 191: 109-119.

Schneider, O., Sereti, V., Eding, E. H. and Verreth, J. A. J. 2005. Analysis of nutrient flows in integrated intensive aquaculture systems. Aquac. Eng., 32: 379-401.

Shyne Anand, P. S., Kohli, M. P. S., Kumar, S., Sundaray, J. K., Dam Roy, S., Venkateshwarlu, G., Sinha, A. and Pailan, G. H 2014. Effect of dietary supplementation of biofloc on growth performance and digestive enzyme activities in Penaeus monodon. Aquaculture, 418-419: 108-115.

Soderhall, K. 1982. Prophenoloxidase activating system and melanisation: a recognition mechanism of arthropods?. Dev Comp. Immunol., 6: 601-611.

Soderhall, K. and Cerenius, L. 1992. Crustacean immunity. Ann. Rev. Fish Dis., 2: 3-23.

Stuart, J. A., Frank, E. C., Chris, J. J., and Sarah, A. G. 2009 High-intensity, zero water-exchange production of juvenile tiger shrimp, Penaeus monodon: An evaluation of artificial substrates and stocking density. Aquaculture, 293, 1-2: 42- 48.

Touratier, F., Legendre, L. and Vezina, A. 1999. Model of bacterial growth influenced by substrate $\mathrm{C}: \mathrm{N}$ ratio and concentration. Aquat. Microb. Ecol., 19: 105-118.

Tseng, W. Y. 2009. Shrimp mariculture. A practical manual. Chien Cheng Publisher, Taiwan. 305 pp.

Vazquez, L., Alpuche, J., Maldonado, G., Agundis, C., PereyraMorales, A. and Zenteno, E. 2009. Review: Immunity mechanisms in crustaceans. Innate Immun., 15(3): 179-188.

Viau, V. E., Souza, D. M., Rodriguez, E. M., Wasielesky, W., Abreu, P. C. and Ballester, E. L. C. 2012. Biofilm feeding by postlarvae of the pink shrimp Farfantepenaeus brasiliensis (Decapoda Penaeidae). Aquac. Res., 44(5): 783-794.

Wang, J. and Yin, X. 2009. Growth of marine bacteria and ammonium regeneration from substrates in different $\mathrm{C}: \mathrm{N}$ ratios. Acta Oceanol. Sin., 28: 59-64.

Wasielesky, Jr. W., Atwood, H., Stokes, A. and Browdy, C. L. 2006. Effect of natural production in a zero exchange suspended microbial floc based super-intensive culture system for white shrimp Litopenaeus vannamei. Aquaculture, 258: 396-403. 
Wooten, E. C., Dyrynda, E. A., Pipe, R. K., and Ratcliffe, N. A. 2003. Comparisons of PAH induced immunomodulation in three bivalve molluscs. Aquat. Toxicol., 65: 13-25.

Xu, W. J., Morris, T. C. and Samocha, T. M. 2015. Effects of C/N ratio on biofloc development, water quality and performance of Litopenaeus vannamei juveniles in a biofloc-based, highdensity, zero-exchange, outdoor tank system, Aquaculture, S0044-486(15): 30249 pp.

Xu, W. J. and Pan, L. Q. 2012. Effects of bioflocs on growth performance, digestive enzyme activity and body composition of juvenile Litopenaeus vannamei in zero-water exchange tanks manipulating $\mathrm{C} / \mathrm{N}$ ratio in feed. Aquaculture, 356: $147-152$.

Zhang, B. 2011. Influence of the artificial substrates on the attachment behaviour of Litopenaeus vannamei in the intensive culture condition. Int. J. Anim. Vet. Adv., 3(1): 37-43.

Zhao, P., Huang, J., Wang, X. H., Song, X. L., Yang, C. H., Zhang, X. G. and Wang, G. C. 2012. The application of bioflocs technology in high-intensive, zero exchange farming systems of Marsupenaeus japonicas. Aquaculture, 354-355: 97-106. 